\title{
USE OF PATHOGENICITY AND PROTEIN ELECTROPHORESIS TO DISTINGUISH ISOLATES OF Macrophomina phaseolina PATHOGENIC ON COTTON Abdel-Sattar, M.A. ${ }^{1}$; A.A. Aly ${ }^{2}$ and M.R. Omar ${ }^{2}$ 1- Dept. of Agric. Bot., Fac. of Agric., Suez Canal Univ., Ismailia, Egypt. 2- Plant Pathology Research Institute, Agric. Res. Center, Giza, Egypt.
}

\section{ABSTRACT}

Twenty eight isolates of Macrophomina phaseolina were tested for levels of pathogenicity on 45-day-old greenhouse-grown seedlings of trhee cotton cultivars. Isolate $X$ cultivar interaction was a very highly significant $(0.0000)$ source of variation in infected seedlings suggesting that isolates responded differently to different cultivars. Due to the significance of isolate $X$ cultivar interaction, a least significant difference (LSD) was used to compare between the individual isolate means within cultivars, based on these comparisons, it was easy to differentiate between some of M. phaseolina isolates by their differential pathogenicity on some of the tested cultivars. On the other hand, some isolates were indistinguishable because they showed nonsignificant differences on any of the cultivars. Proteins of the isolates were compared by sodium dodecyl sulfate-polyacrylamide gel electrophoresis (SDSPAGE). Gels were stained with silver nitrate (SN). Cluster analysis of the protein banding patterns by the unweighted pair-group method based on arithmetic means placed the isolates in several groups; however, grouping the isolates was not related to their virulence, geographic origin, or host. Some isolates, which were indistinguishable by pathogenicity test, were easily distinguished by their protein banding patterns. The results of the present study indicate that isolates of $M$. phaseolina pathogenic on cotton could be identified by their differential pathogenicity on a set of cotton cultivars, combined with their specific protein banding patterns separated by SDS-PAGE and stained with SN.

\section{INTRODUCTION}

Macrophomina phaseolina (Tassi) Goid., the causal agent of charcoal rot (ashy stem) on cotton, is a seed-borne and soil-borne pathogen with a wide distribution and a wide host range (Dhingra and Sinclare, 1978). When M. phaseolina invades roots or stems of cotton, colonization of internal tissues proceeds rapidly and the plant dies. Examination of affected parts reveals a dry rot, with many tiny black sclerotia distributed throughout the wood and softer tissues (Watkins, 1981). A negative correlation ( $r=-0.85, p$ $<0.01$ ) was found between disease incidence and yield (Turini et al., 2000).

Macrophomina phaseolina (Tassi) Goid. is of a widespread distribution in the Egyptian soil, and it is easily and frequently isolated form cotton roots particularly during the late period of the growing seasons. Thus, when Aly et al. (1996) conducted a survey encompassed 88 samples of infected cotton roots from 12 governorates, $M$. phaseolina was isolated from $37.5 \%$ of the samples examined.

Although initial infections of cotton by $M$. phaseolina occur at the seedling stage, they usually remain latent until the cotton plant approaches maturity (Dhingra and Sinclare, 1978). However, M. phaseolina appears to affect some cotton cultivars less severly than others, suggesting the existence of some level of resistance to M. phaseolina (Watkins, 1981; Lee et 
Abdel-Sattar, M.A. et al.

al., 1986; Monga and Raj, 1996 and 2000, and Turini et al., 2001). In Egypt, resistance to $M$. phaseolina is completely lacking in the commercial cottons (Gossypium barbadense L.) (Aly et al., 2006).

Differentiation among $M$. phaseolina isolates pathogenic on cotton is important for improving our understanding of the ecology of these isolates and the epidemiology of the disease. The conventional method of differentiation among pathogen isolates is the observation of the differences in virulence when the isolates interact with a set of host genotypes (Aly, 1988; Ahmed et al., 1991; Schilder and Bergstorm, 1990, and Porta-Puglia et al., 1996). However, this method is expensive, time consuming, and may be influenced by variability inherent in the experimental system (Aly, 1988 and Bhatti and Kraft, 1992). Furthermore, the differential disease reactions do not provide information about the genetic relationship among the pathogen isolates (Perez-Artes et al., 1995).

Therefore, another reliable method, either alternative or complementary to that based on the differential interaction between $M$. phaseolina isolates and cotton genotypes, is required for identification of $M$. phaseolina isolates pathogenic on cotton. Electrophoresis of proteins seems to be a suitable method to achieve this goal because the amino acids sequences of polypeptides (components of proteins) are dependent on nucleotide sequences of their coding genes; therefore an analysis of protein variation among isolates of $M$. phaseolina, approximates an analysis of their genetic variation (Markert and Faulhaber, 1965).

Electrophoresis of proteins has been widely used for studying variation in fungal populations. For instance, Zuber and Manibhushanrao (1982) found that polyacrylamide gel electrophoresis patterns of protein reflected marked variation among five differentially virulent isolates of Rhizoctonia solani, the causal organism of rice sheath blight.

Reynolds et al. (1983) found that protein patterns obtained from polyacrylamide gel electrophoresis for five groups (AG-1 to AG-5) of $R$. solani were distinctive and could be distinguished from one another.

El-Akkad (1997) found heterogenecity in protein banding patterns among AG-4 isolates of $R$. solani.

Abd El-Gany (1998) found a clear relationship between geographic origins of $M$. phaseolina isolates and their protein banding patterns, obtained by polyacrylamide gel electrophoresis, which might indicate that $M$. phaseolina is found as non-specialized geographically isolated populations.

Hussein et al. (2000) used cluster analysis to compare between protein banding patterns obtained by sodium dodecyl sulfate-polyacrylamide gel electrophoresis from 17 isolates of multinucleate $R$. solani (AG-4) and one isolate binucleate Rhizoctonia. The analysis provided clear-cut differentiating features between binucleate and multinucleate Rhizoctonia spp. Thus, the binucleate isolate of Rhizoctonia was placed at a separate cluster remotely related to the cluster, which included all the multinucleate isolates of $R$. solani (AG-4). However, the latter cluster was divided into several sub-clusters. The observed differences in protein profiles of the isolates included in this cluster were not related to virulence, geographic origin, or source (cultivar used in 
isolation). These results suggest that AG-4 of $R$. solani is a heterogeneous group of isolates.

The present investigation was initiated to determine whether the isolates of $M$. phaseolina can be distinguished by their differential pathogenicity on a set of cotton genotypes, in conjunction with their electrophoretic protein patterns.

\section{MATERIALS AND METHODS}

\section{Fungal isolates}

Isolates of $M$. phaeolina used in the present study were obtained from the fungal collection of Cotton Disease Research Section, Plant Pathology Research Institute, Agricultural Research Center, Giza, Egypt. The isolates were originally recovered from cotton and other hosts.

\section{Production of $\boldsymbol{M}$. phaseolina inoculum used in soil infestation}

Substrate for growth of the isolates was prepared in 500-ml glass bottles, each bottle contained $50 \mathrm{~g}$ of sorghum grains and $40 \mathrm{ml}$ of tap water. Contents of each bottle were autoclaved for 30 minutes. Isolate inoculum, taken from one-week-old culture on PDA, was aseptically introduced into the bottle and allowed to colonize sorghum for three weeks.

Interaction between cotton cultivars (Gossypium barbadense L.) and isolates of $M$. phaseolina

Twenty eight isolates $M$. phaseolina (Table 1) were used in the present study. Batches of autoclaved clay loam soil were separately infested with inoculum of each isolate at a rate of $40 \mathrm{~g} / \mathrm{kg}$ soil. The inoculum consisted of mycelia and sclerotia growing on sorghum. Infested soil was dispended in 10 $\mathrm{cm}$-diameter clay pots and these were planted with 10 seeds per pot for each of the tested cultivars (Giza 83, Giza 86, and Giza 89). In the control treatments, autoclaved sorghum grains were thoroughly mixed with soil at a rate of $40 \mathrm{~g} / \mathrm{kg}$ of soil. Pots were randomly distributed on greenhouse benches under temperature regime ranged from $19.5 \pm 1.5^{\circ} \mathrm{C}$ to $34 \pm 4^{\circ} \mathrm{C}$. Percentage of infected seedlings were recorded 45 days after planting.

\section{Statistical analysis of the data}

The experimental design of the greenhouse study was a randomized complete block with five replicates (pots). Analysis of variance (ANOVA) of the data was performed with the MSTAT-C Statistical Package. Least significant difference (LSD) was used to compare between isolate means within cultivars. Percentages were transformed into square roots before carrying out the ANOVA to produce approximately constant variance.

\section{Extraction of fungal proteins}

Protein extracts from $M$. phaseolina isolates were prepared according to Hussein (1992) in the following way: Fungal isolates were grown for 22 days at $22-30^{\circ} \mathrm{C}$ on liquid Czapek medium. The mycelium was harvested by filtration through cheesecloth, washed with distilled water several times, and freeze-dried. This frozen mycelium was suspended in phosphate buffer $\mathrm{pH}$ $8.3(1-3 \mathrm{ml} / \mathrm{g}$ mycelium), mixed thoroughly with glass beads, and ground in liquid nitrogen to a fine powder. The ground mycelium was centrifuged at $19,000 \mathrm{rpm}$ for 30 minutes at $0^{\circ} \mathrm{C}$. The protein content in the supernatant was 
Abdel-Sattar, M.A. et al.

estimated according to Bradford (1976) by using bovine serum albumin as a standard protein. If protein concentration was low, protein was precipitated from the clarified supernatant by adding ammonium sulphate at $70 \%$ of saturation $(60 \mathrm{~g} / 100 \mathrm{ml})$ then kept in the refrigerator for $30 \mathrm{hr}$. Pellets, collected by centrifugation at $11,000 \mathrm{rpm}$ for 30 minutes, were re-suspended in phosphate buffer pH 8.3 and subjected to dialysis for $24 \mathrm{hr}$. against the buffer and centrifuged at 11,000 rpm for 30 minutes. Protein was estimated in the obtained supernatant.

Table 1. Geographic origins and sources of $M$. phaseolina isolates used in electrophoresis.

\begin{tabular}{lcc}
\hline solate no. & Geographic origin & Source \\
\hline 1 & Giza & Soybean \\
2 & Giza & Sunflower \\
3 & Beheira & Cotton \\
4 & Kafr E-Skeikh & Cotton \\
5 & Faiyoum & Sesame \\
6 & Giza & Sesame \\
7 & Beheira & Cotton \\
8 & Giza & Cotton \\
9 & Daqahliya & Cotton \\
10 & Daqahliya & Cotton \\
11 & Kafr El-Sheikh & Cotton \\
12 & Giza & Soybean \\
13 & Gharbiya & Cotton \\
14 & Sharqiya & Cotton \\
15 & Assiute & Cotton \\
16 & Minya & Cotton \\
17 & Assiute & Cotton \\
18 & Giza & Cotton \\
19 & Giza & Sunflower \\
20 & Gharbiya & Cotton \\
21 & Sohag & Cotton \\
22 & Nobariya & Sesame \\
23 & Giza & Sunflower \\
24 & Minufiya & Cotton \\
25 & Sohag & Cotton \\
26 & Minufiya & Cotton \\
27 & Sharqiya & Cotton \\
28 & Minya & Purslane \\
\hline & &
\end{tabular}

\section{Sodium dodecyl sulfate-polyacrilamide gel electrophoresis (SDS-PAGE)}

Each supernatant was mixed with an equal volume of a solution consisting of (by volume) $64 \%$ buffer ( $0.15 \mathrm{M}$ Tris- $\mathrm{HCl}, \mathrm{pH} 6.8), 20 \%$ glycerol; $6 \%$ sodium dodecyl sulphate (SDS); $10 \%$ 2-6-mercaptoethanol; and $0.1 \%$ bromophenol blue, before boiling in a water bath for 3 minutes. Twentymicroliter samples ( $40 \mu \mathrm{g}$ of protein) were subjected to electrophoresis in a 5 - 
$20 \%$ gradient polyacrylamide prepared in $0.1 \%$ SDS with a $3.5 \%$ stacking gel (Laemmli, 1970). Electrophoresis was conducted at $10^{\circ} \mathrm{C}$ for $4 \mathrm{hr}$ at 15 and $30 \mathrm{~mA}$ for the stacking and the separating gels, respectively, until the dye band reached the bottom of the separating gel. Electrophoresis was performed in a vertical slab mold $(16 \times 18 \times 0.15 \mathrm{~cm})$. Gels were stained with silver nitrate for the detection of protein bands (Sammons et al., 1981).

\section{Gel analysis}

A gel documentation system (Advanced American Biotechnology 1166 E. Valencia Dr. Unit 6C, Fullerton CA 92631) was used to document the results of SDS-PAGE and to cluster the electrophoretic patterns by the unweighted pair-group method based on arithmetic mean (UPGMA).

\section{RESULTS AND DISCUSSION}

Isolates of $M$. phaseolina differed significantly $(p=0.0000)$ in their pathogenicity on cotton cultivars. Similarly, differences among cotton cultivars were very highly significantly $(p=0.0000)$ when they were tested against $M$. phaseolina isolates. The interaction between $M$. phaseolina isolates and cotton cultivars was a very highly significant $(0.0000)$ source of variation in infection suggesting that isolates responded differently to the tested cultivars (Table 2).

Due to the significance of isolate $X$ cultivar interaction, a least significant differences (LSD) was used to compare between the individual isolate means within cultivars, based on these comparisons, it was easy to differentiate between some of $M$. phaseolina isolates by their differential pathogenicity on the cultivars. For instance, isolate 1 was easily distinguished from isolate 2 on Giza 89. on this cultivar, isolate 2 was significantly more pathogenic than isolate 1 . Similarly, isolates 23 and 24 were distinguished on this cultivar. Giza 83 differentiated between isolates 20 and 21 (Table 3).

Table 2. Analysis of variance of the effect of cotton cultivar, $M$. phaseolina isolate, and their interaction on the percentage of damping-off. Isolates of $M$. phaseolina were used in electrophoresis studies.

\begin{tabular}{|c|c|c|c|c|}
\hline Source of variation ${ }^{a}$ & D.F. & M.S. & F. value & $P>F$ \\
\hline Replication & $\overline{4}$ & 0.153 & 0.4107 & \\
\hline Cultivar (C) & 2 & 10.255 & 27.4391 & 0.0000 \\
\hline Isolate (S) & 28 & 18.113 & 48.4638 & 0.0000 \\
\hline$C \times S$ & 56 & 1.626 & 4.3509 & 0.0000 \\
\hline Error & 344 & 0.374 & & \\
\hline
\end{tabular}

aeplication is random, while each of cultivar and isolate is fixed.

In the present study, SDS dissociated each oligomeric protein into its subunits (Bohinski, 1983). When protein preparation was treated with mercaptoethanol and DSD, the mercaptoethanol disrupted (reduced) all disulfide (-S-S-) bonds present at proteins, whereas the detergent SDS bound to all regions of protein and unraveled all intramolecular protein associations. This resulted in total disruption of associated subunits 
Abdel-Sattar, M.A. et al.

organization and then yielded SDS-carrying highly-anionic polypeptide chains (Clark and Switzer, 1977).

After carrying out the electrophoresis, gels were stained with silver nitrate (SN). Staining with $\mathrm{SN}$ is a highly sensitive visualization technique for detection of the small amounts of proteins, which cannot be seen with Coomassie Brilliant Blue (CBB). Generally SN is 100 -fold more sensitive than CBB (Andrews, 1986). At this point, the question that may arise is why SN did not show the expected staining efficiency in the case of isolates $7,8,13,22$, 24, 26, and 28 (Fig. 1). Ionic amino acid side chains may play an important role in the silver staining of proteins (Andrews, 1986). So, it seems likely that proteins of the previously mentioned isolates had a low content of these and were therefore poorly stained.

Table 3.Effect of the interaction between cotton cultivars and isolates of $\boldsymbol{M}$. phaseolina on percentage of damping-off under greenhouse conditions. Isolates of $M$. phaseolina were used in electrophoresis studies.

\begin{tabular}{|c|c|c|c|c|c|c|c|c|}
\hline \multirow{3}{*}{ Isolate No. } & \multicolumn{6}{|c|}{ Cultivar } & \multirow{2}{*}{\multicolumn{2}{|c|}{ Mean }} \\
\hline & \multicolumn{2}{|c|}{ Giza 89} & \multicolumn{2}{|c|}{ Giza 86} & \multicolumn{2}{|c|}{ Giza 83} & & \\
\hline & $\%$ & $\begin{array}{l}\text { Trans- } \\
\text { formed }\end{array}$ & $\%$ & $\begin{array}{l}\text { Trans- } \\
\text { formed }\end{array}$ & $\%$ & $\begin{array}{l}\text { Trans- } \\
\text { formed }\end{array}$ & $\%$ & $\begin{array}{l}\text { Trans- } \\
\text { formed }\end{array}$ \\
\hline$\overline{1}$ & $38^{b}$ & $(6.11)$ & 72 & $(8.48)$ & 92 & $(9.58)$ & 67.33 & $(8.06)$ \\
\hline 2 & 78 & (8.83) & 82 & (9.04) & 90 & (9.48) & 83.33 & (9.12) \\
\hline 3 & 76 & (8.71) & 76 & (8.71) & 84 & (9.15) & 78.67 & (8.86) \\
\hline 4 & 86 & (9.26) & 84 & (9.16) & 92 & (9.58) & 87.33 & (9.33) \\
\hline 5 & 72 & (8.46) & 70 & (8.37) & 98 & (9.90) & 80.00 & (8.91) \\
\hline 6 & 94 & (9.69) & 80 & (8.94) & 80 & (8.94) & 84.67 & (9.19) \\
\hline 7 & 84 & (9.16) & 80 & (8.94) & 80 & (8.94) & 81.33 & (9.01) \\
\hline 8 & 88 & (9.37) & 76 & (8.70) & 94 & (9.69) & 86.00 & (9.25) \\
\hline 9 & 78 & (8.22) & 76 & (8.71) & 96 & (9.79) & 83.33 & (9.11) \\
\hline 10 & 86 & (9.27) & 84 & (9.14) & 96 & (9.80) & 88.67 & (9.40) \\
\hline 11 & 66 & (8.08) & 72 & (8.36) & 88 & (9.36) & 75.33 & (8.60) \\
\hline 12 & 86 & (9.26) & 90 & (9.47) & 90 & (9.47) & 88.67 & (9.40) \\
\hline 13 & 90 & (9.49) & 94 & (9.69) & 88 & (9.37) & 90.67 & (9.52) \\
\hline 14 & 92 & (9.15) & 82 & (9.01) & 82 & (9.00) & 85.33 & (9.05) \\
\hline 15 & 64 & (7.99) & 90 & (9.49) & 94 & (9.69) & 82.67 & (9.06) \\
\hline 16 & 92 & (9.58) & 82 & (9.15) & 88 & (9.36) & 87.33 & (9.37) \\
\hline 17 & 96 & (9.80) & 94 & (9.69) & 84 & (9.15) & 91.33 & (9.54) \\
\hline 18 & 86 & (9.27) & 94 & (9.78) & 80 & (8.92) & 86.67 & (9.32) \\
\hline 19 & 78 & (8.82) & 80 & (8.92) & 90 & (9.47) & 82.67 & (9.07) \\
\hline 20 & 90 & (9.47) & 92 & (9.58) & 90 & (9.47) & 90.67 & (9.51) \\
\hline 21 & 88 & (9.37) & 94 & (9.69) & 76 & (8.71) & 86.00 & (9.26) \\
\hline 22 & 74 & (8.60) & 74 & (8.60) & 84 & (9.16) & 77.33 & (8.79) \\
\hline 23 & 56 & (7.48) & 88 & (9.37) & 88 & (9.36) & 77.33 & (8.74) \\
\hline 24 & 76 & (8.71) & 90 & (9.47) & 90 & (9.47) & 85.33 & (9.22) \\
\hline 25 & 78 & (8.82) & 90 & (9.47) & 78 & (8.82) & 82.00 & (9.04) \\
\hline 26 & 92 & (9.58) & 90 & (9.58) & 78 & (8.82) & 86.67 & (9.33) \\
\hline 27 & 74 & (8.60) & 90 & (9.49) & 90 & (9.48) & 84.67 & (9.19) \\
\hline 28 & 56 & (7.47) & 84 & (9.26) & 82 & (9.04) & 74.00 & (8.59) \\
\hline Control & 10 & (2.42) & 20 & (4.41) & 16 & (3.52) & 15.33 & (3.45) \\
\hline Mean & 76.69 & (8.61) & 81.72 & (8.99) & 84.76 & (9.12) & 81.06 & (8.91) \\
\hline
\end{tabular}


A problem with proteins as biochemical markers for typing or classification of fungi is the vast number, which can be generated. Faced with so much data, only sophisticated analysis can hope to draw meaningful conclusions. The ready availability of computers has made numerical taxonomy more accessible and some later studies on fungi have proven useful (Manicom et al., 1990).

The phenogram of Fig. 2 was constructed based on similarity levels (SLs) generated from cluster analysis of the electrophoretic banding patterns of SDS-dissociated proteins shown in Fig. 1. The higher the SL, the more closely the isolates were related. Nine groups of isolates were identified by cluster analysis at SLs of 84.17, 63.25, 88.15, 92.05, 99.20, 73.42, 81.02, 74.04 , and 28.13. It is noteworthy that isolates of the latter group were almost completely different from all the other isolates. Among these clusters, clusters 2,4 , and 6 were the three main clusters because they included $15(75 \%)$ of the tested isolates. The observed differences in protein profiles of the isolates included in the different clusters were not related to virulence, geographic origin, or source (host used in isolation). For example, isolates 1 and 23 were significantly different in pathogenicity on Giza 89 and Giza 86; however, they belonged to the same cluster showing a SL as high as $84.17 \%$ in their protein profiles. Isolates 5 and 6 were easily distinguished on Giza 89 and Giza 83; however, they showed almost identical protein profiles. Although isolates 1 and 12 showed striking differences in their protein profiles, they were isolated from soybean plants that were collected from Giza. Cotton isolates and Giza isolates seem to be randomly distributed among clusters.

While it was easy to differentiate between some of $M$. phaseolina isolates by their differential pathogenicity on some of the tested cultivars, some isolates were indistinguishable because they showed nonsignificant differences in pathogenicity on any of the tested cultivars. Such isolates were easily distinguished by their protein banding patterns after staining with $\mathrm{SN}$. For example, isolates 8 and 10 or isolates 13 and 14 were indistinguishable in pathogenicity on any of the tested cultivars; however, they were easily distinguished by their protein banding patterns. Thus, members of each pair of the isolates were placed in two remotely related clusters. Therefore, it seems reasonable to conclude that the observed isolate specific bands may be useful as biochemical markers in ecological studies in soil where "marked" isolates are needed. The differential pathogenicity of $M$. phaseolina isolates, combined with their specific protein bands after staining with $\mathrm{SN}$ would facilitate their identification after reisolation from soil.

Hall (1967) reported that the protein patterns of 12 isolates of Fusarium solani belonging to both parasitic and saprophytic forms varied with age and illumination of cultures, sources of extract, and size of inoculum, but the protein patterns of isolates cultured under standardized conditions were identical. Therefore, we stress that the successful use of SDS-PAGE to differentiate among $M$. phaseolina isolates pathogenic on cotton requires that growth, extraction, and electrophoretic procedures must be carried out under standardized rigorously controlled conditions. 


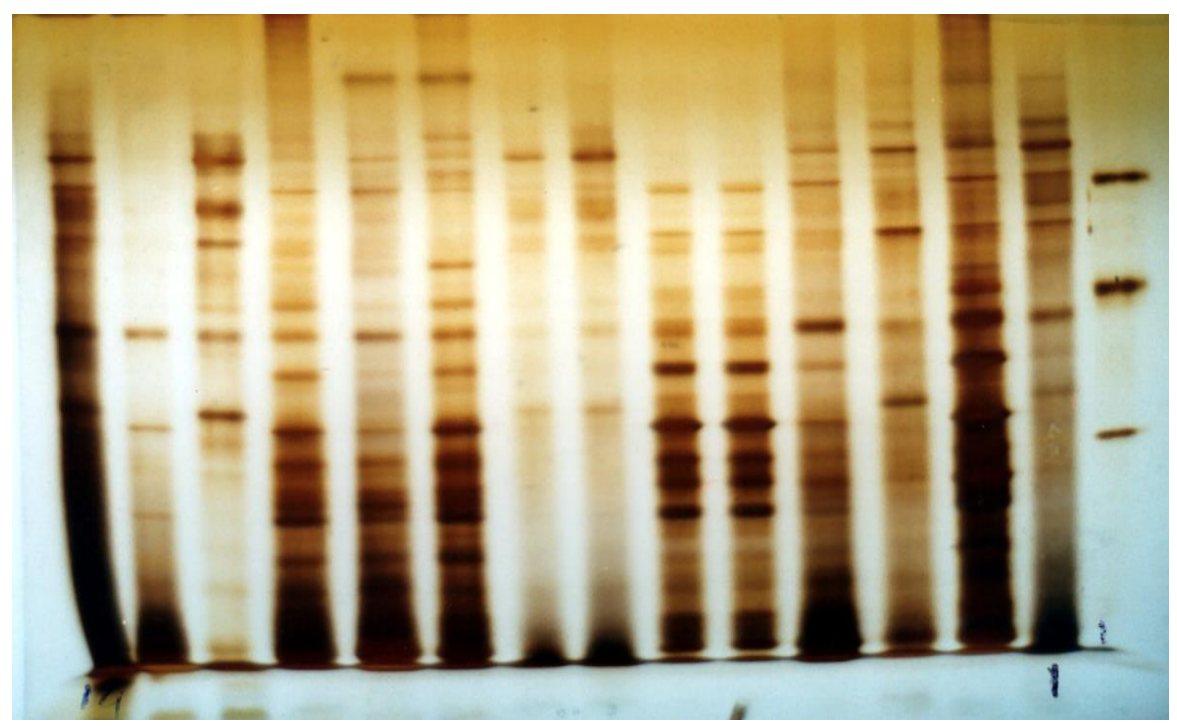

$\begin{array}{llllllllllllll}14 & 13 & 12 & 11 & 10 & 9 & 8 & 7 & 6 & 5 & 4 & 3 & 2 & 1\end{array}$

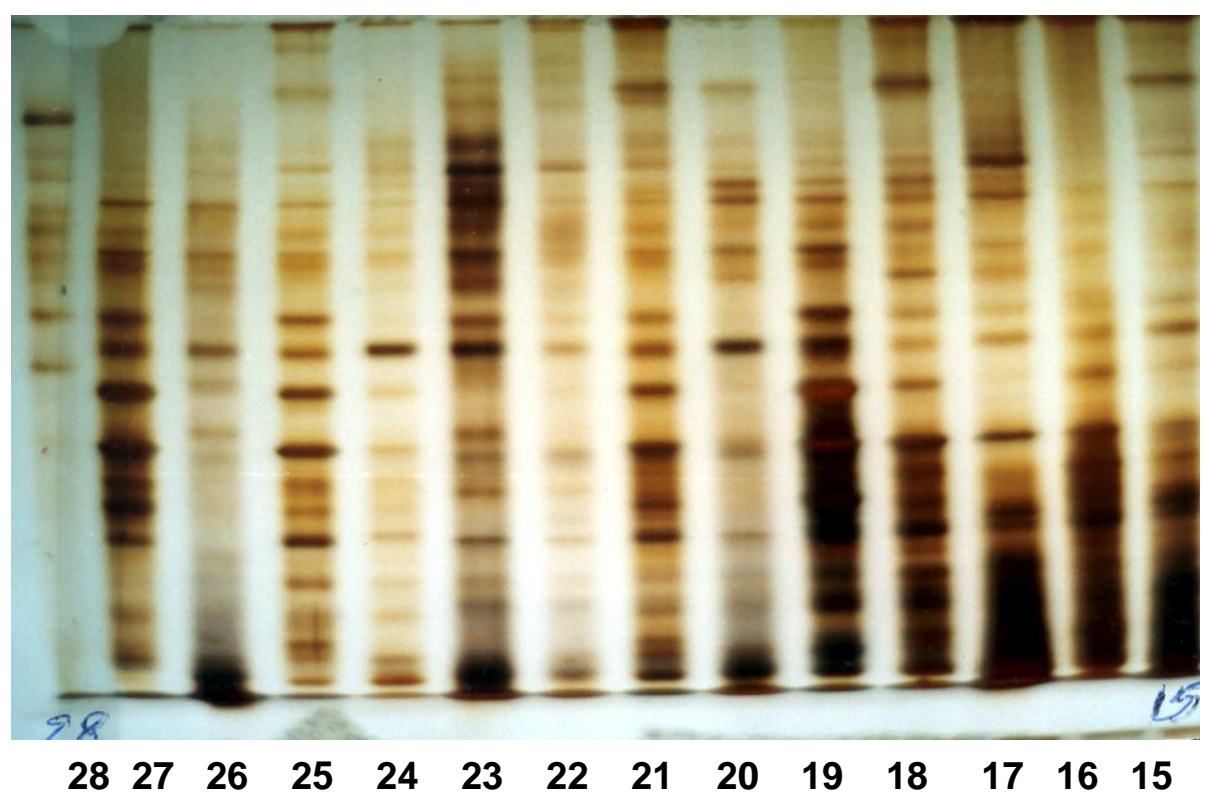

Fig. 1. Protein patterns obtained by SDS-PAGE from 28 isolates of $M$. phaseolina. 
J. Agric. Sci. Mansoura Univ., 33 (1), January, 2008 
Fig. 2. Phenogram based on average linkage cluster analysis of electrophoretic protein patterns obtained by SDS-PAGE from 28 isolates of $M$. phaseolina.

\section{REFERENCES}

Abd El-Gany, H.S. 1998. Physiological, pathological, and biochemical comparative studies on Macrophomina phaseolina isolated from different hosts. Menofiya J. Agric. Res. 23: 885-906.

Ahmad, I., K. Burney and M. Aslam. 1991. Analysis of resistance in sunflower to charcoal rot pathogen Macrophomina phaseolina. Pakistan Journa of Botany 23: 189-193.

Aly, A.A. 1988. Incidence of Fusarium wilt of flax as influenced by biotic and abiotic factors. Ph.D. Thesis. South Dakota State Univ., Brookings. 173 p.

Aly, A.A., E.M. Hussein, M.A. Mostafa, and A.I. Ismail. 1996. Distribution, identification, and pathogenicity of Fusarium spp. Isolated from some Egyptian cottons. Menofiya J. Agric. Res. 21: 819-836.

Aly, A.A., M.A. Abdel-Sattar, and M.R. Omar. 2006. Susceptibility of some Egyptian cotton cultivars to charcoal rot disease caused by Macrophomina phaseolina. J. Agric. Sci. Mansoura Univ. 31:50255037.

Andrews, A.T. 1986. "Electrophoresis: Theory, Techniques, and Biochemical and Clinical Applications", 2nd Ed. Oxford Univ., Press, Oxford. $452 \mathrm{p}$

Bhatti, M.A. and J.M. Kraft. 1992. The effects of inoculum density and temperature on root rot and wilt of chickpea. Plant Disease 76:50-54.

Bohinski, R.C. 1983. "Modern Concepts in Biochemistry", $4^{\text {th }}$ Ed. Allyn and Bacon, Inc., Newton, Massachusetts. 531p.

Clarck, J.M., Jr. and R.L. Switzer. 1977. "Experimental Biochemistry", $2^{\text {nd }}$ Ed. W.H. Freeman and Company, New York and San Francisco. 335p.

Dhingra, O.D., and J.B. Sinclair. 1978. "Biology and pathology of Macrophomina phaseolina". Imprensia Universidade Federal de Viscosa, Brazil $166 \mathrm{p}$.

El-Akkad, S.A.F. 1997. Studies on anastomosis groups of Rhizoctonia solani. Ph.D. Thesis. Cairo Univ., Cairo. 143 p.

Hall, R. 1967. Protein and catalase enzymes from Fusarium solani and their taxonomic significance. Aust. J. Biol. Sci. 20:419-428.

Hussein, E.M. 1992. Biochemical and serological studies for determining susceptibility of cotton cultivars to Fusarium oxysporum f.sp. vasinfectum (in Russian). Ph.D. Thesis. All-Union Institute of Plant Protection. Leningrad, USSR.

Hussein, E.M., A.D.A. Allam, A.A. Aly, A.M. Amein, and A.M.A. El-Samawaty. 2000. Separation by protein electrophoresis of Rhizoctonia spp. isoalted from cotton seedlings. J. Agric. Sci., Mansoura Univ. 25: 40354046 . 
Laemmli, U.K. 1970. Cleavage of structural proteins during the assembly of the head of bacteriophage T4. Nature 227: 680-685.

Lee, C.C., L.S. Bird, P.M. Thaxton, and M.L. Howell. 1986. The association of Macrophomina phaseolina with cotton. Acta Phytophylactica Sinica 13: 169-173.

Manicom, B.Q., M. Bar-Joseph, and J.M. Kotze. 1990. Molecular methods of potential use in the identification and taxonomy of filamentous fungi, particularly Fusarium oxysporum. Phytophylactica 22: 223-239.

Markert, C.L. and I. Faulhaber. 1965. Lactate dehydrogenase isozyme patterns of fish. J. Exp. Zool. 159: 319-332.

Monga, D. and S. Raj. 1996. vertical screening against root rot of cotton in sick fileds. Crop Research Hisar $12: 82-86$.

Monga, D. and S. Raj. 2000. Screening of germplasm lines against root rot of cotton (G. hirsutum). Advances in Plant Science 13: 603-607.

Perez-Artes, E., M.I.G. Roncero, and R.M. Jimenes-Diaz. 1995. Restriction fragment length polymorphism analysis of the mitochondrial DNA of Fusarium oxysporum f.sp. ciceris. J. Phytopathology 143:105-109.

Porta-Puglia, A., P. Crino, and C. Mosconi. 1996. variability in virulence to chickpea of an Italian population of Ascochyta rabiei. Plant Dis. 80: 3941.

Reynolds, M., A.R. Weinhold, and I.J. Morris. 1983. Comparison of anastomosis groups of Rhizoctonia solani by polyacrylamide electrophoresis of soluble proteins. Phytopathology 73: 903-906.

Sammons, D.W., L.D. Adamas, and E.E. Nishizawa. 1981. Ultra-sensitive silver based color staining of polypeptides in polyacrylamide gels. Electrophoresis 2: 135.

Schilder, A.M.C., and G.C. Bergstrom. 1990. Variation in virulence within the population of Pyrenophora tritici-repentis in New York. Phytopathology 80: 84-90.

Turini, T.A., E.T. Natwick, G.G. Cook, and M.E. Stanghellini. 2000. Upland cotton varietal response to charcoal rot. Proceedings of the Beltwide Cotton Conference. Volume 1:147-148.

Turini, T.A., E.T. Natwick, and G.G. Cook. 2001. Upland cotton varietal response to charcoal rot. Proceedings of the Beltwide Cotton Conference. Volume 1: 140-141.

Watkins, G.M. ed. 1981. Compendium of cotton diseases. The American Phytopathological Society. St. Paul., Minnesota. 87p.

Zuber, M., and K. Manibhushanrao. 1982. Studies on comparative gel electrophoresis patterns of proteins and enzymes from isolates of Rhizoctonia solani sheath blight disease in rice. Can. J. Microbiol 28: 762-771.

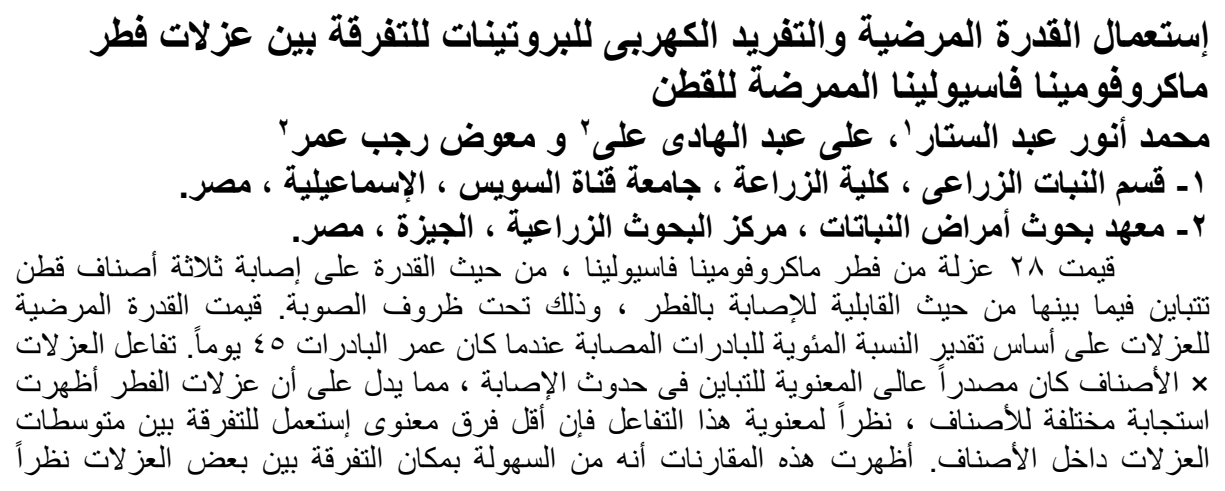




\section{Abdel-Sattar, M.A. et al.}

للإختافات المعنوية فيما بينها من حيث القدرة على إصابة بعض الأصناف ، فى حين لم يمكن التفرقة بين

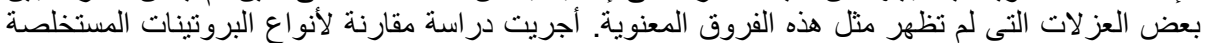

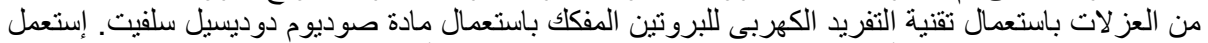

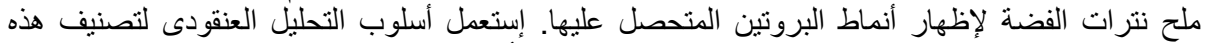

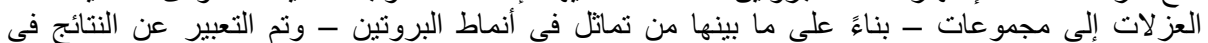

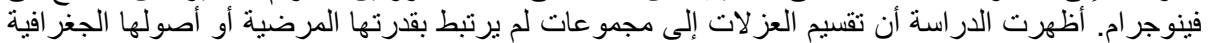

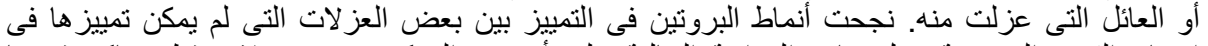

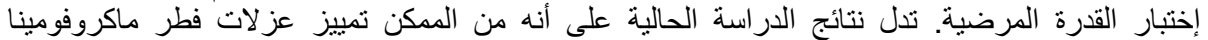

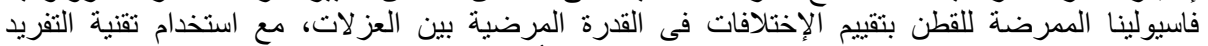
الكهربى للبروتين الدفكل ، ثم الصبغ بنترات الفضة لإظهار أنماط البروتينات المميزة لهذه العزلات التئ. 